\title{
Pituitary Cell Turnover: From Adult Stem Cell Recruitment through Differentiation to Death
}

\author{
Montserrat Garcia-Lavandeira Esther Diaz-Rodriguez Dilek Bahar
}

Angela R. Garcia-Rendueles Joana S. Rodrigues Carlos Dieguez

Clara V. Alvarez

Neoplasia and Endocrine Differentiation, Centre for Investigations in Medicine (CIMUS), Instituto de Investigaciones Sanitarias, School of Medicine, University of Santiago de Compostela, Santiago de Compostela, Spain

\section{Key Words}

Stem cells $\cdot$ Pituitary $\cdot$ Pituitary tumors $\cdot$ Hypopituitarism .

Ret $\cdot$ GDNF $\cdot$ Pit-1 $\cdot$ Arf $\cdot$ p53

\begin{abstract}
The recent demonstration using genetic tracing that in the adult pituitary stem cells are normally recruited from the niche in the marginal zone and differentiate into secretory cells in the adenopituitary has elegantly confirmed the proposal made when the pituitary stem cell niche was first discovered 5 years ago. Some of the early controversies have also been resolved. However, many questions remain, such as which are the markers that make a pituitary stem cell truly unique and the exact mechanisms that trigger recruitment from the niche. Little is known about the processes of commitment and differentiation once a stem cell has left the niche. Moreover, the acceptance that pituitary cells are renewed by stem cells implies the existence of regulated mechanisms of cell death in differentiated cells which must themselves be explained. The demonstration of an apoptotic pathway mediated by RET/caspase 3/Pit-1/Arf/p53 in normal somatotrophs is therefore an important step to-
\end{abstract}

wards understanding how pituitary cell number is regulated. Further work will elucidate how the rates of the three processes of cell renewal, differentiation and apoptosis are balanced in tissue homeostasis after birth, but altered in pituitary hyperplasia in response to physiological stimuli such as puberty and lactation. Thus, we can aim to understand the mechanisms underlying human disease due to insufficient (hypopituitarism) or excess (pituitary tumor) cell numbers.

(c) 2015 S. Karger AG, Basel

\section{Introduction}

The pituitary gland produces six different hormones from five secretory cell lineages: GH (produced by somatotrophs), PRL (lactotrophs), TSH (thyrotrophs), ACTH (corticotrophs), FSH and LH (gonadotrophs). In rodents, melanotropes concentrate in the intermediate lobe (IL). Secretory cell lineages are also defined by specific transcription factors that induce and maintain cell differentiation and the production of hormones such as Pit-1, Tpit and Sf1. One of the most interesting features

\section{KARGER 125}

(c) 2015 S. Karger AG, Basel

0028-3835/15/1013-0175\$39.50/0

E-Mail karger@karger.com

www.karger.com/nen
Clara V. Alvarez

CIMUS, Instituto de Investigaciones Sanitarias

School of Medicine, University of Santiago de Compostela

c/ Barcelona s/n, ES-15782 Santiago de Compostela (Spain)

E-Mail clara.alvarez@usc.es 
of the pituitary gland is its plasticity leading to hypoplasia or hyperplasia during physiological changes such as puberty, pregnancy and lactation $[1,2]$. Although the existence of plastic pituitary growth responses has been known for many years, the recent characterization of pituitary stem cells implies the possibility of defining the mechanisms involved in pituitary cell renewal and cell death. Furthermore, it may also help to shed light on the mechanisms involved in pituitary tumorigenesis. Again in contrast to other tissues, pituitary adenomas are quite frequent in the general population (up to $14.4-22.5 \%$ depending on whether autopsy or radiological studies are used for calculation), while pituitary carcinomas are very rare [3]. Thus, the pituitary gland offers a unique model system in which to determine both the role played by stem cells in cell renewal and how cell 'plasia' is balanced in different periods of life.

Others have already amply reviewed the discovery of postnatal stem cells (also called adult stem cells, ASC) in the adenopituitary (AP) with a detailed historical development of the field [4-6]. The present review focuses on more recent data. Two main points are stressed throughout the text, the first being markers. ASC are defined by the coexpression of markers common to all ASC residing in different niches throughout the body, together with organ-specific markers. Common markers are stem cell markers already present in embryonic stem cells (ESC; e.g. Sox2, Oct4, Klf4) [7-10] or immediately after implantation (e.g. Sox9) [11-17]. Among these common markers, we must now include the GFR-alpha/RET [a tyrosine kinase receptor with 4 'alpha' coreceptors (GFRa1-1) and 4 respective ligands (GDNF, NRTN, ARTM, PSPN)] family of receptors, first described in 2009 for the pituitary stem cells but also demonstrated in testes ASC and in the preimplantation blastocyst [18-23]. The very recent publication in Nature, demonstrating that bone marrow stem cells (BM-ASC) also coexpress all GFR-alpha/RET receptors which are essential for BM-ASC survival after birth [24], indicates that expression of this family of receptors is an intrinsic characteristic common to all ASC. On the other hand, as one organ-specific marker, Prop1 is characteristic of pituitary ASC. Second, this review specifically relates data on stem cells from the niche to those on pathways of programmed cell death in differentiated secretory cells, with the aim of forming an overview of cell turnover in the AP. We feel that the knowledge generated in this area can serve as a model for niches of epithelial origin in glands throughout the body as well as furthering our understanding for the future management of pituitary tumors.

\section{ASC in the AP}

ASC Are Derived from the Marginal Zone of the AP, a Niche Conserved from Rodents to Humans

Overall, work using single cell-type populations purified by flow cytometry was pioneering and produced a lot of information on the behavior of putative stem cells in vitro [25-29]. However, a definitive marker of adult pituitary stem cells, using similar criteria to those in other organs, was not identified, probably because flow cytometry enriches but does not fully purify cell populations.

In 2008, stained sections of the whole pituitary identified groups of cells with nuclei positive for Sox2 in the marginal zone (MZ) but also throughout the AP [30]. Primary pituitary cultures produced cell spheres that were positive for Sox2/Sox9/E-cadherin/nestin/Sca1/S100, with rare differentiated secretory cells also present. Within the spheres, a few Sox2+ cells were Sox9-. Further investigation in pituitary sections also revealed a double Sox $2+/$ Sox $9+$ and a single Sox $2+/$ Sox9- population. As apparently the Sox $2+/$ Sox 9 - cells retained BrdU, suggesting that they were slowly dividing, while the Sox $2+/$ Sox9+ did not, the authors proposed that the Sox $2+/$ Sox $9-$ population comprised ASC, with the Sox $2+/$ Sox $9+$ cells being derived from them and constituting transit-amplifying cells (TAC) [30].

In 2009, a second group described the existence of a spatially distinct niche of pituitary stem cells conserved in humans and rodents (rats and mice) [18]. In agreement with the previous study [30], it was found to be located in the MZ. The niche was found to comprise at least two rows of cells that are negative for hormone expression, with the first row of cells situated in the IL and extending to the first row of AP cells $[15,18]$. The main population of the niche coexpress receptors of the GFR-alpha/RET family (Gfra2, Gfra3, RET), together with the differentiation-essential transcription factor Prop1 and bona fide ESC markers (Sox2, Sox9, KLF4; fig. 1). The cells of this well-organized population were therefore named 'GPS' (for GFRa-RET/Prop1/Stem markers). In common with ESC, GPS cells express the glycolipid stage-specific embryonic antigen- 4 , high levels of cytokeratins and betacatenin, suggesting strong cell-to-cell adhesion $[15,16$, 18]. Adjacent to GPS, another population expressing S-100 or nestin were also observed. None of the niche cells express hormones or any characteristic pituitary transcription factors such as Pit-1.

Functional analysis of GPS cells has shown that they retain BrdU when injected at postnatal day 1 and analyzed 2 months later by immunofluorescence on sections, 
showing that they rarely divide [18]. Consistent with this, when telomere length was quantified in the same sections using fluorescence in situ hybridization (telomapping), the longest telomeres in the pituitary were found in the two rows of the MZ [18]. Thus, GPS cells can be regarded as a group of nonactively dividing cells, an essential characteristic of ASC found in other physiological niches such as the bone marrow and skin.

Ongoing Question: Which Are the True Stem Cells, Those Expressing Single or Multiple Markers of Stemness? Importance of Coexpression for the

Maintenance of the Stem Steady-State in GPS

The functional distinction between a differentiated cell and a stem cell is widely accepted: differentiated cells carry out a physiologically relevant activity (e.g. secretion of a hormone), while stem cells are relatively quiescent and protected from stimuli that might induce their commitment. The biological basis of this distinction, however, is becoming blurred as we gain knowledge from studies of naturally occurring ESC and artificially obtained induced stem cells (iPS). For example, we now know that certain characteristic markers of a stem cell are also expressed by many differentiated cell types. Thus, ESC express Oct4, Sox 2 and Klf4, but each of these three markers is also expressed in intestinal mucosa, hematopoietic and neuronal cells. This apparent contradiction is also seen in the pituitary. As shown in figures 1 and $2 \mathrm{a}$, it is not only the GPS cells of the niche that express markers such as Sox2, Sox9, Gfra2, RET and Klf4, but cells expressing those markers are also scattered throughout the AP [15, $18,30,31]$.

Is GPS a single stem cell population or are there multiple GPS? Which is more stem: the coexpressing cell at the niche or the single-expressing cell in the AP? What molecular events occur during recruitment and commitment? The distinction between cells in different commitment stages is entirely speculative, largely due to technical limitations. Immunocytochemistry, for example, is restricted by the number of truly specific antibodies that can be used in combination. Many putative markers belong to large gene families (such as Sox or Klf) which share domains with conserved sequences, limiting the number of truly specific polyclonal antibodies. Mouse monoclonal antibodies are specific, but problematic to use in mouse tissues. Furthermore, it is difficult to combine primary antibodies from more than three species (rabbit, mouse and goat) in rat pituitary immunocytochemistry, due to cross-reaction of secondary antibodies.

Adenopituitary Cell Turnover
To overcome some of these limitations, different strategies have been explored such as staining pituitary sections with groups of two or three stem markers. This led to the conclusion that the GPS stem cells in the niche are those which coexpress all markers (Gfra2, Gfra3, RET, Prop1, Sox2, Oct4, Klf4, Sox9, SEA4, beta-catenin, cytokeratin, E-cadherin, vimentin) $[15,18]$, whilst some nonGPS cells that each express only a single stem marker are also present, interspersed among the GPS cells of the first row of the AP and within the rest of the AP (fig. 1). When niche GPS cells are double positive for any two markers, e.g. Gfra2+/cytokeratin+ or Sox $2+/$ cytokeratin+, interspersed AP cells are positive for only one of those markers, e.g. Gfra2+/cytokeratin- or Sox $2+/$ cytokeratin-, respectively (fig. $1 b, c)$. Thus, while the majority of niche cells are double positive for example for Sox $2 /$ cytokeratin, there were scattered Sox 2 groups through the AP but low in cytokeratins (fig. 1c). An intriguing additional feature to have emerged from this analysis is that the multiple-positive expression characteristic of the niche is also seen in the AP follicles. Although definitive proof is lacking, the staining suggests that the follicles could be tubular continuations of the niche as proposed by S. Correr in the 1980s and recently by other groups [31-35] (fig. 1ce). Thus, the stem cell epithelium of the MZ might form papillae extending into the AP. In sections, such papillae would appear round and hollow, like follicles. However, while attractive, these hypotheses of stem and differentiated cell organization in the AP remain to be thoroughly tested.

Many groups have described isolated cells within the AP presenting cytoplasmic Gfra2, Sox2, Sox9 or Prop1 staining [15, 18, 30, 31, 36] (fig. 1b, c, e, f). But another level of complexity resides in the subcellular localization of the stem markers. For example, while in the niche, the Sox 2 and Sox 9 transcription factors are coexpressed in the nucleus of GPS cells, within the AP, Sox9+/Sox2- cells are frequently found with cytoplasmic localization. The same is true for Sox $2+$ cells in the AP, negative for Sox 9 and a few with cytoplasmic localization (fig. 1f) $[15,18]$.

Thus, there is an ongoing debate as to whether true stem cells are those expressing single or multiple markers in the AP. A particular challenge in resolving the issue is that of following the trajectories of individual putative stem cells, due to the lack of markers of commitment to characterize the TAC population. However, the pituitary genetic tracing in animal models (see below) appears to support the view towards stem cells being those that are positive for multiple markers. Moreover, studies on ASC in organs and tissues other than the pituitary, together

Neuroendocrinology 2015;101:175-192 DOI: $10.1159 / 000375502$ 
with the data outlined above for the AP, now make it plausible to hypothesize that single-marker-expressing cells interspersed in the AP have left the niche and become either committed, progenitor or TAC for a specific type of pituitary cell (fig. 1).

Work comparing ASC in other organs with ESC has indeed highlighted that ESC always coexpress at least four essential markers, Oct4, Sox2, Klf4 and Nanog, which in turn drive the expression of characteristic genes such as Rex1, Tbx3, Esrrb, alkaline phosphatase, ABC transporters, telomerase, E-cadherin and beta-catenin. These genes regulate each other causing their 'domino-ed' coexpression $[7,8$, and reviewed in $9,10,16]$. Transcription factors essential to stemness also heterodimerize, increasing the number of ways in which stem cell genes are regulated. Sox9, while not considered an essential ESC marker, is expressed from implantation and remains a characteristic gene of ASC.

Since ASC reside in discrete niches within organs they express not only the main stem cell markers but also at least one marker that is characteristic of the or- gan niche. For example, lung and pituitary ASC have common markers such as Oct4, Sox2, Klf4 and Sox9 (fig. 1), while only pituitary GPS coexpress Prop1 [16, $37,38]$. In humans and rodents, Prop 1 mutations result in combined hypopituitarism with an apparently normal gland at birth, both in anatomical location and in volume [39-44]. At the molecular level, it is known that Prop1 drives commitment and thus, depending on the partner with which Prop1 dimerizes, it can repress (dimer with TLE) or activate (dimer with beta-catenin) the Pit-1 promoter during embryonic development [45]. After birth, Prop1 is expressed in GPS and, as the other stem markers, its expression decreases with age $[18,36]$. Using a different antibody, Prop1 also labels scattered cells in the AP [36]. Prop1 cells colocalize with Sox2, although not all Sox 2 cells colocalize with Prop1. The role of Prop1 in GPS recruitment after birth will need to be more fully characterized in the future. New partners of Prop1, such as AES, may also have a role in this temporal regulation [46].

arrow). $\mathbf{d}$ In the human MZ, GPS cells also coexpress GFRa receptors (shown GFRa3), RET and stem cell markers such as SOX2, OCT4 and KLF4. e GPS cells express GFRa2 (red) or Sox2 (red) but no nestin (green). Nestin appears throughout the three parts of the gland (NP, IL and AP) following a pattern of thin and elongated tubular-like positive cells $[18,54-56]$. However, a few nestin + cells with long extensions (green) are detected in the proximity of GPS, both in the niche and follicles $[18,31]$. These nestin+ cells contain their own nucleus (white arrows) and are negative for GFRa2 and Sox2. Occasionally, prolongations of these nestin+ cells can be seen touching the GPS (arrowheads and yellow merged dots in double GFRa2+Nestin). A GFRa2+ cell outside a follicle is also shown (black arrow). $\mathbf{f}$ In the adult pituitary, the niche has a low proliferative activity. Fixation does not always separate the rows of the $\mathrm{MZ}$, and the space between the two stem cell rows is seen to be minimal. Sox9 labeling (green, nuclear) is higher at the row of niche cells facing the IL, but is also expressed by the neuropituitary pituicytes. Sox2 (red, nuclear) is strongly expressed by both cell rows in the niche but is less expressed in the neuropituitary. To assess proliferation, this rat was injected in vivo with BrdU (blue, nuclear) $12 \mathrm{~h}$ before removing the pituitary. Usually one or two dividing cells in the niche can be seen per hemipituitary. Shown is a dividing cell in the niche, located between the rows (asterisk). At the niche, Sox $9 /$ Sox 2 -coexpressing cells are a majority (white arrowheads, yellow merge). In the anterior row, increasing Sox $2+$ nuclei are seen (white arrows). Within the AP, there are cells with single positive whole cell or nuclear Sox9+ (black arrows), cells with single Sox2 (white arrows) and few cells with double Sox9/Sox2 labeling (arrowheads). Nuclei are counterstained with DAPI (grey).

(For figure see next page.) 


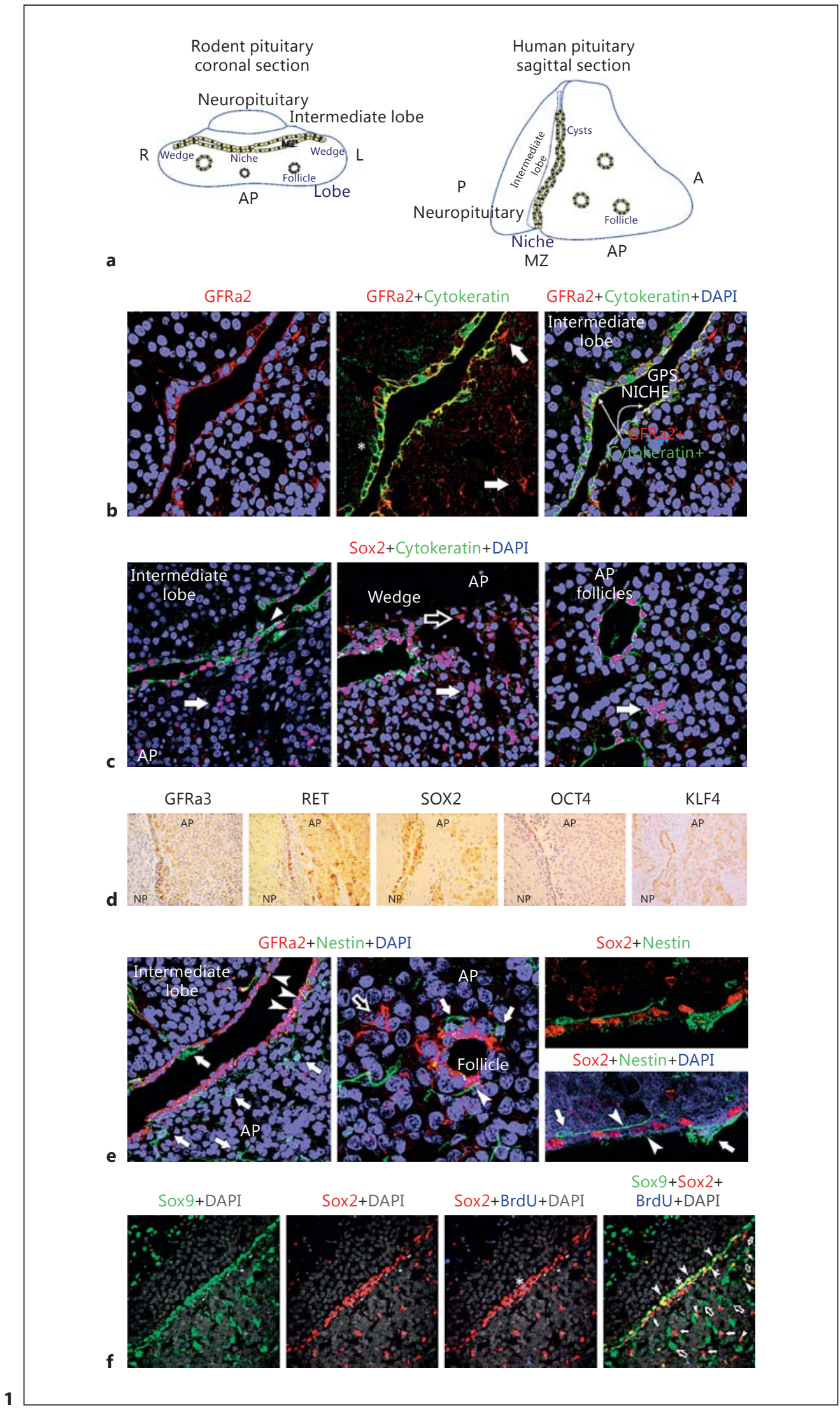


It appears that the maintenance of multipotency in ESC is due to a 'balance' between the coexpressed markers, because as soon as any one factor becomes expressed more highly than the others, the cell starts to become committed. Sox 2 overexpression in ESC, for example, induces a neuroectodermal fate with a concomitant loss of endoderm potential; conversely, Oct 4 overexpression induces endoderm [47-50]. This is similar to what happens in ASC. Intestinal stem cells, for example, are LGR5+high/ SOX2+high/SOX9+low, but enteroendocrine-committed precursors are Sox9+high $[12,51]$.

The mechanisms that underlie this subtle balance of expression in ASC versus those that induce commitment are gradually being revealed. Recently, it has been shown in neural stem cells that to maintain stemness the core genes must be transcribed in 'oscillatory waves' with a period of a few hours. When any one of those factors stops oscillating and starts to be continuously expressed, the neural stem cell becomes a progenitor of oligodendrocytes, neurons or astrocytes, depending on the factor that becomes continuously expressed [52].

Is the Pituitary Niche a Three-Dimensional Structure of GPS, Nestin-Negative Parenchymal and Nestin-

Positive Mesenchymal Stem Cells?

Nestin is an intermediate filament protein expressed in many cell-type progenitors during embryogenesis and in some populations postnatally. For many years, nestin has been proposed as a marker of neural stem cells [53], but as it is also characteristic of committed and differentiating neurons during embryonic development, its role as a stem cell marker is evolving. In the AP, nestin was first described as being present in the three lobes of the gland following a pattern of thin and elongated tubularlike staining but absent in secretory hormone-expressing cells $[18,25,54-56]$. The pattern of staining could be related to folliculostellate cells. Folliculostellate cells are S-100+ nonendocrine cells situated adjacent to the acini and surrounding the follicles. For long they have been regarded as pituitary follicular stem cells [57]. However, pituitary nestin + cells do not coexpress S-100 [54], and folliculostellate cells already have the assigned role of paracrine signal integrators [2].

Using transgenic mice expressing GFP under the control of specific fragments of the nestin promoter, it was found that all cells around the MZ expressed GFP together with stem markers [58]. Crossing nestin-promoterCRE and loxP-GFP mice, these cells were traced as they became positive for hormone expression during commitment and differentiation. The study concluded that stem cells in the postnatal niche of the MZ cells express nestin and that they renew the secretory cell populations after birth. Data gathered more recently led to further gain of knowledge in this area by characterizing the nestin-Cre activity and nestin expression itself in the context of the hypothalamus-pituitary axis both in the embryo and in the adult [59]. It was shown that Nestin-Cre mice, widely used to dissect gene and cell function in the CNS, in addition to other side effects and pitfalls associated with Cre activity or transgene insertion (anemia, glucose intolerance, chromosome rearrangements) are affected by mild hypopituitarism. Hence, the need to use nestin-Cre control samples to distinguish real consequences of deletion of the gene under investigation from side effects resulting from nestin-Cre-associated hypopituitarism. When this was taken into consideration, it was revealed that in the same Nestin-promoter-CRE-GFP mice from the previous work, GFP staining did not colocalize with endogenous nestin expression [59]. This elegant study is in keeping with previous ones using double labeling that indicated an absence of nestin expression in cells that were Sox $2+$ or Gfra2+ in the MZ $[18,30,54]$.

In addition, it should be taken into account that in postnatal stem cell niches described for many organs, several populations coexist with the true stem cells of the parenchyma, e.g. mesenchymal stem cells (MSC), endothelial and neural [reviewed in 16]. Nestin has recently been described as a bona fide marker of MSC together with PDGFRa, surrounding capillaries and residing with hematopoietic stem cells in the bone marrow niche [6063]. In the CNS, however, it has been proposed that nestin is expressed in any proliferating cell, whether a stem or progenitor cell, or a cell in tissue under repair [64].

Staining in rat pituitary suggests that nestin+ cells in the normal pituitary might also be MSC since they do not colocalize with GPS stem cell markers [18, 30, 54] (fig. 1e). Consistent with this hypothesis, a recent study in human pituitary adenomas has suggested that nestin is expressed by a population of endothelial-type cells but not by secretory, folliculostellate or MZ 'parenchymal' (GPS) cells $[56,65]$. If this interpretation turns out to be correct, the niche would constitute a well-organized three-dimensional structure in which GPS cells are strongly attached to each other [hence the high levels of beta-catenin and cytokeratin expression (fig. 1b, c)], and supported by nestin-expressing MSC (fig. 1e).

Other cell populations might also be present in the niche, as suggested for example by the expression of vimentin, another intermediate filament protein, which is abundantly expressed by post-implantation embryonic 
undifferentiated precursors but not by pluripotent ESC $[66,67]$. Vimentin continues to be expressed by many precursors in adult organs, although it is also expressed in some differentiated cell types such as endothelial cells. In the pituitary, vimentin is highly expressed in the MZ [18] (fig. 2a). However, it is expressed by different cell population on both sides of the niche, rather than exclusively by GPS cells. Taken together with the data for nestin expression (fig. 1e), it appears that the pituitary niche contains populations of MSC of which some cells might be associated with endothelium of adjacent capillaries as happens in the bone marrow $[60,62]$.

The niche is already present at birth in rats and humans and shows functional regulation $[15,18]$. Immunostained sections of normal human pituitaries from a 2-month-old girl, a 4-year-old boy and 2 adults demonstrated GPS cells in the MZ that were positive for Oct4, Klf4, Gfra3 and RET [15] (fig. 1d). Stem cell markers in rats are highly expressed just after birth (day P1) and decline continuously from the onset of puberty (P10) and through adulthood (P90) [18]. Postnatal rat pituitaries contain many more Ki67+ cells at the niche than those of the adult [18] (fig. 1f). After birth, the numbers of Prop1+ and Prop $1+/$ Sox $2+$ cells progressively decrease with age in rats [36]. In the mouse, the proportion of Sox $2+$ cells in total pituitary cells also decreases with age after birth [68].

\section{From Adult Stem to Committed and Differentiated Cells in the AP}

In vitro Evidence: The Transition from Stem to

Differentiated Secretory Cells

Whilst cells recruited from the niche will lose expression of at least most stem cell markers, little else is known about their trajectory through commitment and differentiation. This is largely attributable to a lack of appropriate markers for studying these processes in vivo. Therefore, current understanding is based on in vitro studies. Different aspects of ASC development have been addressed according to the methods used.

Immunocytochemistry of ultrafine pituitary sections shows that RET is expressed by cells on both sides of the niche that also have cilia (fig. 2a). As discussed above, GPS stem cells express RET and its Gfra2/3 coreceptors. Gfra coreceptors are proteins located on the extracellular aspect of the plasma membrane and help RET bind to its ligands. Therefore, specific purification of Gfra2+ cells with magnetic beads followed by in vitro conditions de- signed for stem cell culture (e.g. no serum) have been used [18] (fig. 2b). After 5 days of culture, the Gfra2+, but not the Gfra2- fraction, grows as spheres that present cilia and move within the well (fig. 2c). These spheres are reminiscent of blastocysts, which have also been shown to express Gfra3 receptors [21-23]. The spheres are positive for stem markers and negative for hormones, and are able to actively grow even from seeding a single Gfra2+ cell per well (fig. $2 \mathrm{~d}$, e). Spheres can also be obtained by culturing unpurified single-cell pituitary dispersions under similar conditions, but some of these 'pituispheres' contain mixed cells that express hormones [30, 31]. Recently, Sox 2 and Sox9 promoter-driven GFP+ pituitary stem cells, fluorescent cells purified by flow cytometry, have also been cultured as pituispheres, demonstrating that cells with clonogenic potential (able to self-renew and differentiate in vitro) in the adult pituitary were contained in the Sox $2+$ and Sox9+ cell compartment. When differentiation was not induced, only inconstantly peripheral hormone-expressing cells were seen [69-71]. These studies demonstrate that purification is an important step in in vitro studies of ASC commitment and differentiation.

Spheres are induced to differentiate in random directions by attachment to coated surfaces in the presence of serum or can be directionally differentiated in the presence of a cocktail of growth factors, hormones, or conditioned medium from pituitary cell lines [18, 30, 31]. Additives required for somatotroph induction are, unsurprisingly, different from those for other cell types, e.g. gonadotroph induction. But as all methods have entailed the use of mixed cocktails, it is not clear either what the essential factors are or, more importantly, the sequence in which they should be added to induce commitment and differentiation of an ASC to a particular secretory cell type.

While it is essential to elucidate the molecular mechanisms of the transition from stem to differentiated cell, in vitro studies using purified pituitary ASC are time-consuming and require many animals. An alternative model is that of mouse embryonic development, based on the reasoning that embryonic ASC follow identical pathways but more rapidly. Many studies have demonstrated the importance of BMP and FGF pathways to formation of the Rathke's pouch precursors in the essential hypothalamus-pouch connection during pituitary development, and the sonic hedgehog, a ligand of the hedgehog family (SHH), Wnt/beta-catenin and notch pathways to commitment/differentiation of those precursors [reviewed in $2,44]$. In this context, a heterozygous $\mathrm{SHH}$ mutation had 


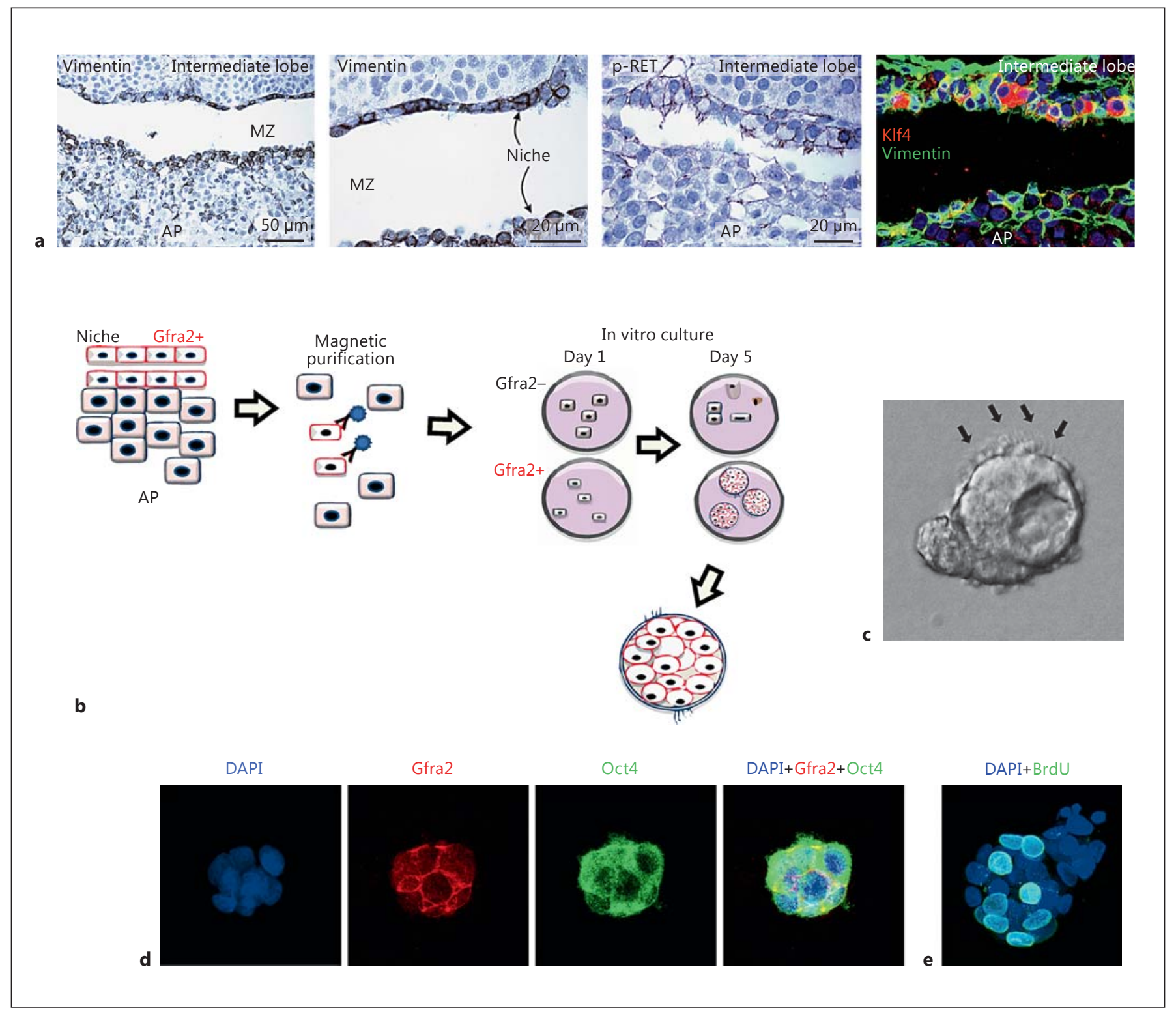

Fig. 2. GPS stem cells have multiple cilia and grow in vitro as ciliated spheres expressing stem cell markers. a Ultrafine paraffin sections $(3 \mu \mathrm{m})$ of the pituitary gland immunostained for vimentin and phospho-RET. Cilia can be detected on the surface of cells in both rows of the niche as described [32-34]. Right: Double immunofluorescence for KLF4 (red) and vimentin (green). Anti-KLF4 exclusively stains the GPS cells, and on this occasion is only located at the row towards the IL. In thin paraffin sections $(3 \mu \mathrm{m})$, the first row facing the IL is always a continuum of GPS cells. However, the first row facing the AP does not always appear with GPS except when approximating the lateral wedges. This suggests an undulated shape of the niche in the AP side. Anti-vimentin stains the whole niche, including other cell types that could be MSC or endothelial cells. As in many organs $[60,115,116]$, capillaries are probably located close to the niche as already suggested for the pi- tuitary in electron microscopy studies [32-34]. b The culturing method for purified GFRa2+ stem cells. Pituitary dispersions are incubated with anti-GFRa2 antibody coupled to magnetic beads, obtaining GFRa2+ and GFRa- fractions. Only the GFRa2+ population gives rise to spheres. c Some of these spheres move through the culture well and present cilia. $\mathbf{d}$ The spheres express similar stem markers as niche cells in vivo. Shown is double staining for GFRa2 (red) and Oct4 (green). Nuclei are counterstained with DAPI (blue). GFRa2, a membrane marker, shows intracellular staining (perinuclear endoplasmic reticulum, Golgi) but membrane reinforcement (red lines), while the nuclei appear empty. Oct4, a transcription factor, is translated at the cytoplasm but shows nuclear reinforcement [18]. e Addition of BrdU for a few hours before fixation demonstrates active proliferation in the spheres. 
recently been found in a human female patient with combined pituitary hormone deficiency among other alterations [72].

Another strategy is to study how ESC cultures can be committed and differentiated into pituitary secretory cells by the sequential addition of factors. In 2011, using mouse ESC cell aggregation Sasai's group obtained oral ectoderm-like cell aggregates [positive for pituitary-embryonic transcription factor (Pitxla)] in connection with hypothalamic-like sheets [positive for hypothalamic-embryonic transcription factor (Rx)] [73]. After this, they looked for and found the most efficient treatment to induce commitment to Rathke's pouch precursors (double Pitxla+, oral ectoderm/Lhx3+, Rathke's pouch). The aggregates with a shape reminiscent of Rathke's pouch and the highest intensity of Pitx1+/Lhx3+ expression were those cultured for 10 days in the presence of an agonist of the Shh pathway.

After this, several strategies were used to induce differentiation with, in general, poor efficiency. For example, to obtain somatotrophs a lengthy culture period with a beta-catenin agonist, cortisol and insulin was required to obtain less than $6 \%$ of GH+ cells of the Rathke's pouchlike aggregates [73]. Differentiation of corticotrophs, on the other hand, had an efficiency of more than $40 \%$ of the Rathke's pouch-like aggregates using a notch inhibitor in the presence of hyperoxia (40\% partial pressure). One explanation of this result is that notch inhibits Tpit (Tbx19), a transcription factor essential for corticotroph differentiation. Transplantation of the differentiated aggregates into hypophysectomized mice injected with $\mathrm{CRH}$ restored endogenous production of corticosterone, locomotor activity and survival [73].

In 2013, similar results were obtained with human ESC and iPSs [74]. Cell aggregates were maintained for 30 days in Matrigel in the presence of a TGF-beta inhibitor to prevent mesenchymal differentiation. During this period, the following factors were added sequentially: first, noggin (a BMP inhibitor) for 3 days which induced formation of a placode-like epithelium (an anterior ectoderm derivative); second, $\mathrm{SHH}$ for 5 days, and finally, a notch inhibitor for 5 days. Again, the main cell type obtained was corticotrophs while there was a poor efficiency in Pit-1 derivatives. The aggregates secreted detectable hormones when transplanted into normal nude mice and rats.

In summary, therefore, it appears from in vitro studies that commitment of AP stem cells involves modulation of the BMP pathway followed by activation of the hedgehog pathway $(\mathrm{SHH})$ and modulation of the notch pathway. Subsequent commitment and differentiation may require other pathways. It remains to be shown whether recruitment from the niche to differentiation in the intact adult pituitary is due to the same sequence of steps suggested by in vitro studies to date.

\section{In vivo Tracing: Following the Differentiation}

Trajectory of AP GPS Stem Cells in the AP

From the studies discussed in the first part of this review, it is clear that in the pituitary there is a niche located in the margin between the IL and AP whose main cell population consists of ciliated epithelial cells (expressing e-cadherin and cytokeratin) that are strongly attached to each other (submembrane beta-catenin expression) and coexpress stem cell markers (Gfra2/Gfra3, RET, Prop1, Oct4, Sox2, Sox9, Klf4 and SEA4). However, to demonstrate that the function of the niche is to maintain or replenish differentiated endocrine cells of the pituitary after birth requires cell-tracing experiments (fig. 3). The most common approach is to permanently label stem cells using an inducible genetic strategy in mice (e.g. expression of fluorescent proteins such as GFP). Cells and their progeny are then located at subsequent time-points to observe whether they have left the niche and, if so, ultimately given rise to differentiated cells (coexpression of secretory hormones). An alternative approach is to induce damage in an AP population through genetic strategies to ascertain whether cells from the niche repopulate the damaged area.

Tracing strategies have to be very precise with controls that demonstrate, first, that the promoter fragment used correlates with endogenous expression of stem markers seen in the pituitary, and second, that the inducer of the permanent modification (usually tamoxifen, doxycycline, or diphtheria toxin) does not itself affect the experiment. As discussed above, the first model to use such a labeling strategy was the nestin-GFP mouse, which produced nonoptimal results due to not being correlated to the pituitary-endogenous nestin expression $[58,59]$.

An initial genetic mouse model study in relation to pituitary stem cells used the Cdk4 knockout (KO) but did not use tracing [18]. Cdk4 is a kinase that binds D-type cyclins to regulate proliferation. In the adult skin, it has been demonstrated to be essential for the recruitment of progenitors in the so-called transit-amplifying state to become differentiated $[75,76]$. Cdk4 KO mice presented dwarfism with hypopituitarism due to a small hypoplastic pituitary [77]. It was observed that the pituitary of the Cdk4 KO maintained normal proportions of endocrine cells but accumulated GPS cells (Sox2 and Sox9) at the niche with long telomeres, as if they were not being re- 


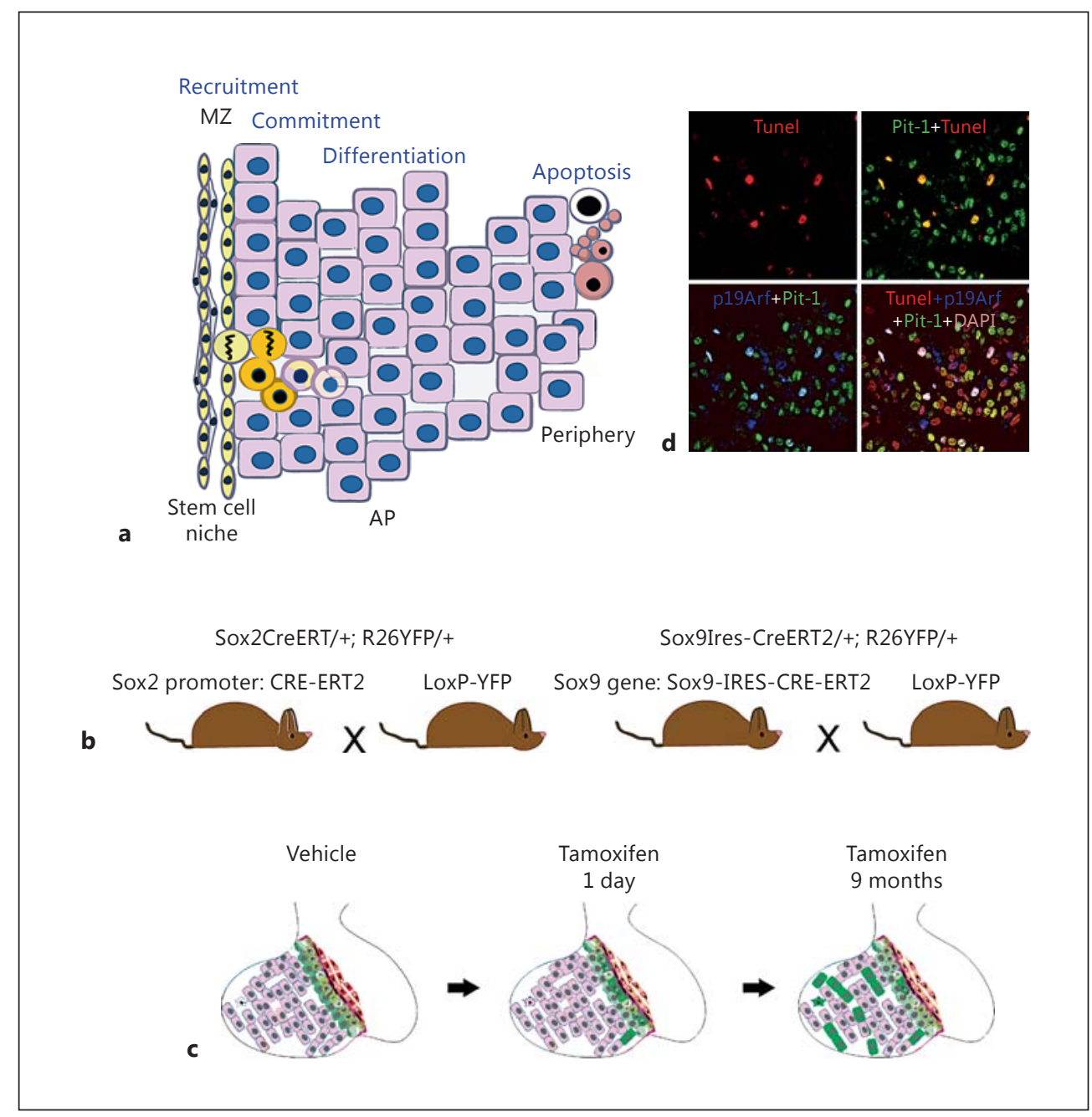

Fig. 3. Pituitary cell turnover maintains cell number in the normal AP. a The niche MZ to be composed of parenchymal GPS cells (yellow) (GFRa2/GFRa3/Ret/Prop1/Sox2/Sox9/Oct4/Klf4/SEA4/ cytokeratin/bCat+) and other types of cells (green), such as elongated MSC (nestin/vimentin+). Progenitors are recruited from the niche and become committed and differentiated into secretory cells. Outside the niche, while they are already committed but undifferentiated, cells lose coexpression of most GPS markers (remaining markers shown as orange) while gaining expression of differentiated transcription factors (blue nuclei). Once they are differentiated, the cells lose all stem markers and instead express differentiation markers such Pit-1 or hormones (blue, pink). A specific marker of committed progenitor cells has not yet been described (orange). When differentiated cells become dysfunctional, they normally enter an apoptotic pathway. For somatotrophs, the apoptotic RET/Pit-1/Arf dependence receptor pathway takes place in the AP periphery. $\mathbf{b}$ The two models that have demonstrated that niche stem cells are recruited and become secretory endocrine cells after birth $[70,71]$. Two genes expressed in pituitary stem cells were chosen, Sox 2 and Sox9. In one mouse the CRE recombinase regulated by tamoxifen (CRE-ERT2) was regulated by the Sox 2 or Sox 9 endogenous promoter. In the second mouse, an EYFP gene expressing fluorescent protein (YFP) was controlled by a general expressing promoter, but an initial LoxP element blocks expression. Crossing the mice and injecting tamoxifen causes the CRE recombinase to be activated exclusively in Sox2- or Sox9-expressing cells. The LoxP element is thus remodeled in those cells, and they become permanently fluorescent, expressing YFP that can be detected either directly or with anti-GFP antibodies. In both models, short time after tamoxifen injection (1-2 days), fluorescent GFP cells are detected only at the niche and coexpress stem cell markers. However, months after the injection, YFP cells are detected scattered throughout the AP coexpressing hormones or differentiated transcription factors such as Pit-1. d Four-color immunofluorescence demonstrating that TUNEL+ cells (red) at the periphery of an adult (90 days) male rat AP strongly express Pit-1 (green, nuclear) and p19Arf, the p53 inducer (blue, nuclear). Nuclei are counterstained with DAPI (brown). A few Pit-1-negative cells express cytoplasmic Arf. In the normal AP, only a few Pit-1 cells are apoptotic (TUNEL+/Pit-1, orange merge) via the RET/ Pit-1/p19Arf/p53 pathway. Excess Pit-1 activates the Arf promoter (Pit-1+/p19Arf + , cyan merge). All these markers are nuclear (pink merge: TUNEL+Pit-1+p19Arf+DAPI) [95]. 
cruited and/or differentiating normally [18]. When a dominantly acting protein mutant Cdk4 (R24C) [78] was knocked in in the Cdk4 KO mouse, the mice recovered normal growth with a pituitary normal in size, but with age-related pituitary tumors. The Cdk4 KO mouse presents a similar phenotype in other endocrine glands, such as the pancreas, which can also be rescued with the R24C mutant $[79,80]$, suggesting that endocrine stem cells need this enzyme for normal cell cycle regulation after birth.

Using in vivo models where diphtheria toxin induced a sudden and massive elimination of endocrine populations, it was suggested that Sox $2+$ cells were able to repopulate the adult pituitary. However, repopulation was not quantitatively consistent, and there was no tracing of the stem cells to demonstrate conversion into differentiated secretory cells $[81,82]$. Opposite results were gathered by using mild models of corticotroph death, where it was discarded that Sox $2+$ cells contributed to repair, although again no fate-mapping techniques were used [83]. Using models affecting both the hypothalamus and the pituitary, such as the POMC-CRE/loxP-DICER mouse, indicates that hypothalamic factors are required for normal niche activation, recruitment and/or differentiation [84].

The latter two models were published in back-to-back articles at the end of 2013, and together demonstrate for the first time in vivo that the pituitary can generate new endocrine cells from niche stem cells postnatally (fig. 3b, c) and also respond actively to adrenal gland injury regenerating specifically corticotrophs, an idea initially suggested in the late 1990s [85].

Lovell-Badge's group [70] has used two models of pituitary stem cell tracing, in which either the Sox 2 or Sox 9 endogenous promoter drives expression of a tamoxifeninducible CRE recombinase (CRE-ERT2). There is also a more fundamental difference between these models. In the Sox 2 mouse, the CRE-ERT2 allele substitutes the coding region of one of the two Sox 2 alleles, and thus the mouse is hypomorphic or permanently deficient $\left(\operatorname{Sox} 2^{+/-}\right)$ [86]. This model has been validated and recapitulates endogenous Sox 2 expression in all organs studied. In the other model, however, CRE-ERT2 is integrated after the endogenous Sox9 locus as a knock-in with an IRES (Sox9IRES-CRE-ERT2). Thus, both Sox9 alleles are conserved, which is essential since Sox9 heterozygosity is lethal at birth [87]. For the pituitary studies, both Sox2- and Sox9models were crossed with R26-stop-EYFP mice. These mice contain an Enhanced Yellow Fluorescent Protein gene (YFP) inserted into the Gt(ROSA)26Sor locus. Ex- pression of EYFP is blocked by an upstream loxP-flanked STOP sequence. After tamoxifen injection, the loxP site recombines, and Sox $2+$ or Sox9+ cells become permanently labeled with YFP, allowing them to be traced over time either by direct fluorescence or by detection with anti-GFP antibodies (which cross-react with YFP). When tamoxifen is injected at the end of pregnancy or at birth, the niche is the main YFP-expressing area. Weeks later, YFP cells appear throughout the pituitary and coexpress hormones or transcription factors characteristic of secretory cells (LH, ACTH, Pit-1). YFP-expressing cells harvested immediately after tamoxifen injection grow as pituispheres in vitro [70]. These authors also studied classic functional responses. Thus, as expected, estradiol pellets induced proliferation of Sox2+ YFP cells in the Sox2CRE-ERT2 model, while acute adrenalectomy increased the number of corticotrophs, and at least $20 \%$ of these new corticotrophs were derived from Sox9+ YFP cells in the Sox9-CRE-ERT2 model. In general, there were no major differences between the two models in relation to the niche, and thus evidence was obtained for what we had intuitively proposed in 2009 [18] that double Sox $2+1$ Sox $9+$ cells are the true pituitary stem cells. However, the efficiency in labeling with YFP stem cells after excising the loxP sequences was higher in the Sox2CreERT2 mice compared with the Sox9CreERT2 mice. This could be an intrinsic genetic difference but also could reflect the bigger number of Sox $2+$ cells in the pituitary located both at the niche (Sox2+/Sox9+) but also within the AP (Sox $2+/$ Sox9-) (fig. 1c, d, f). In these mouse models, there are some intriguing results such as the poor conversion of YFP cells into GH+ cells, while green gonadotrophs ( $\mathrm{LH})$ or PRL are easily counted [70]. The authors suggest that tamoxifen (weak estrogen) itself influences the direction of commitment taking place, although there could be other explanations as well (see below). Technically, this would mean that tamoxifen-inducible models have limits in studies of the pituitary.

The second article is from Martinez-Barbera's group [71] and uses their own Sox2CreERT2 model of Sox2 promoter tracing. Crossing this mouse with a loxP-EYFP mouse to generate a tamoxifen-traceable model produced similar data to those obtained with the previous model, although with a $25 \%$ lower dose of tamoxifen. Initial coexpression of YFP, Sox 9 and Sox 2 after tamoxifen injection was concentrated in the niche, and then YFP was traced to the AP and every type of secretory cell therein [71]. Interestingly, it shows GFP to be expressed in folliculostellate cells (S100b+), and therefore that niche cells are responsible not only for secretory cell renewal but for 
every known type of pituitary cell. Alternatively, since many Sox 2 cells at the niche also express S100, increased detection of GFP/Sox $2 / S 100$ could be an indication of self-renewal of Sox 2 cells. Additionally, the same study found that only $30 \mathrm{~h}$ after tamoxifen injection, when nearly all YFP cells are still Sox2-expressing stem cells, there was already a few Pit-1+/GFP+ cells [71]. This suggests that Pit-1+ cells, the main pituitary population, are the fastest renewed. Purified YFP+ but not YFP- cells were also able to form in vitro colonies that expressed stem markers and able to differentiate into secretory cells. A second part of the same report [71] analyzes the role of the exon-3 point mutation in beta-catenin in the generation of craniopharyngiomas (CRP; see below).

In summary, recent results from stem cell tracing confirm dual expression of Sox 2 and Sox9 in GPS cells and demonstrate that the adult pituitary has a normal capacity for renewal of its cells by recruiting stem cells from the niche; even though both articles indicate that in the longterm experiments only a small percentage of endocrine cells derived from the induced YFP+ niche cells is found, suggesting low renewal. However, there are two reasons that could contribute to this: first, the population of already committed cells (double Sox $2 /$ Sox $9+$ but still not positive for hormones), untraceable by the GFP antibody, which finally become differentiated endocrine cells (this is suggested in Rizzoti et al. [70]); second, the existence of a physiological cell death in the pituitary that prevents accumulation of fluorescent cells as part of a turnover maintaining a stable cell number in the adult gland.

\section{Apoptosis and Its Equilibria with Stem Cell Recruitment in the AP}

\section{Balance of AP Cell Numbers: An Apoptotic Pathway}

That Could Offset AP Renewal by Stem Cells

Until very recently, it has been broadly accepted that once the pituitary reached its definitive size, cell renewal was negligible. There were some stages in which it was accepted that limited proliferation took place, such as in early postnatal life, around puberty and, in females, during pregnancy and lactation [1]. If another primary organ gland such as the thyroid failed, the pituitary could also compensate. In all these cases, the mechanism was assumed to be proliferation of terminally differentiated (or more recently dedifferentiated) secretory cells, as if they were able to return back to proliferation. So, the discovery of a pituitary stem cell niche (from 2008 to 2012, as discussed in the first section) and of recruitment of cells from it throughout life and in response to damage (described in 2012 and discussed in the second section) is a significant conceptual change. Indeed, it suggests that cells of the pituitary have a limited lifespan and are continuously renewed, which in turn raises the question of where programmed cell death might be occurring in the AP.

Specifically, should we expect there to be a particular area discrete from the niche or interspersed apoptotic cells, either in proximity to or separate from newly recruited cells? The few detailed studies on normal rates of apoptosis in the AP date from the 1990s and a TUNEL technique with low sensitivity colorimetric staining. Conclusions from those studies in the 1990s were that pituitary apoptosis in normal women was very low or undetectable, and increased by a factor of five in pregnancy and postpartum, as well as in adenomas (see below) [88]. Electron-microscopic studies also failed to detect apoptosis in the normal pituitary [89]. However, while electron microscopy is very useful for subcellular morphological details and thus discriminating between different stages of apoptosis where it is very abundant, it is not sensitive to lower rates of apoptosis, which is a rapid process, the products of which are also rapidly engulfed by other cells. Nowadays, the most sensitive and widely accepted technique for detecting apoptosis is labeling with the activated caspase 3 (aCasp3) antibody (see below) alone or in combination with a most sensitive biotinylated/peroxidase TUNEL. It could well be that the very low but detectable $0.01 \%$ of apoptosis in normal human pituitary obtained with previous techniques could become a low but relevant percentage of apoptosis with a newer more sensitive technique.

To discuss normal pituitary apoptosis, we have to return to the RET receptor which is not only coexpressed with the Gfra2 coreceptor in GPS stem cells, but in somatotrophs is coexpressed exclusively with the Gfra1 coreceptor $[90,91]$. The ligand that activates these complexes is GDNF, also expressed in both rat and human AP. In a detailed molecular study, RET has been shown to act as a dependence receptor in somatotrophs [92]. This is a novel type of receptor in which survival of the cell expressing it becomes absolutely dependent on the extracellular presence of the ligand: as soon as the receptor no longer receives sufficient signaling, it becomes intracellularly processed by caspases and an apoptotic pathway is activated [93]. Many receptors belong to the family of dependence receptors, such as Ptch1, DCC, ALK, TrkA, TrkC and the androgen receptor. Compellingly, in the pituitary the RET dependence pathway is mediated by 
Pit- 1 and thus associated with differentiation. In somatotrophs, when GDNF is not present RET forms a complex with caspase 3 and PKC-delta (PKCd). Once this complex is formed, caspase 3 is activated to aCasp3, which processes RET and PKCd, and this phosphorylates transcription factors such as CREB and cEBPa, leading to uncontrolled Pit-1 transcription $[92,94]$. Excess Pit-1 in turn induces p19Arf transcription, p53 accumulation and apoptosis [95].

The RET/Pit-1/Arf/p53 pathway has been demonstrated not only in cell lines and primary cultures but also in in vivo animal models. For example, the Ret knockout causes pituitary hyperplasia at birth due to excess somatotroph numbers, while a retrovirus expressing Ret can prevent estrogen-induced hyperplasia [92]. The apoptotic pathway has a survival correlate when the ligand is present: GDNF prevents RET processing, inducing dimerization, tyrosine kinase activation and phosphorylation of intracellular proteins $[92,95,96]$. One of the activated survival pathways involves Akt, which represses Pit-1 expression to levels insufficient to initiate apoptosis and compatible with life and GH production.

Recently, in the normal male pituitary gland, the existence of TUNEL-positive cells that coexpress Pit-1 (GH) and p19Arf has been demonstrated [95] (fig. 3d). These cells appear to be more plentiful in the periphery of the AP, i.e. at the greatest distance from the niche. The majority of healthy somatotrophs, on the other hand, were found to be negative for TUNEL and Arf, but positive for phospho-Ret, which recognizes GDNF-activated Ret. Together, these recent data suggest that there is a discrete group of AP cells undergoing apoptosis, due either to insufficient levels of GDNF or to an intrinsic failure in their survival response to it. It would also be logical for a majority of apoptotic cells to be somatotrophs as they are the main secretory cell type in the AP.

Other groups have obtained comparable data in the female pituitary, where RET is expressed not only in somatotrophs but also in a few lactotrophs [97]. During pregnancy and lactation, there are very few RET+ cells that also present aCasp3. However, in the days following weaning when lactation is suppressed, the number of Ret+/aCasp3+ cells increases substantially. Although that study does not include triple staining to verify that the Ret+/aCasp3+ cells are lactotrophs, there are also data to suggest that the RET/Pit-1/apoptotic pathway exists in lactotrophs where it is involved in returning the AP to its normal size after lactation, by triggering programmed cell death in lactotrophs [97]. Another apoptotic pathway depending on autocrine dopamine production has been de- scribed in lactotrophs after weaning, suggesting redundant apoptotic pathways for ensuring physiological turnover [2, 98].

In summary, the RET/Pit-1/Arf/p53 apoptotic pathway in differentiated AP cells is involved in maintaining a balance between secretory function and cell number. The antagonistic survival pathway is RET/GFRa1/GDNF which could itself be related to the stem cell niche by virtue of RET also being expressed by GPS cells of the niche but with different coreceptors (Gfra2, Gfra3).

\section{Abnormal AP Cell Numbers: Are Pituitary Adenomas} due to Altered Differentiation of Stem Cells or Failure of Secretory Cell Apoptosis?

Pituitary adenomas are benign tumors. A few genetic alterations have been described as initiators in some sporadic or familial adenomas [99]. While pluripotent cancer stem cells are not expected to be present, the possibility that pituitary adenomas are derived from niche GPS cells which have undergone a genetic alteration in the recruitment and/or differentiation process has not been excluded [4]. Indeed, there have been cases of acromegaly in which the tumors express all pituitary hormones [100]. Alternatively, adenomas could originate from differentiated secretory cells that become resistant to apoptosis and thus immortal while dividing only very slowly [96].

A few studies have investigated the presence of cells expressing stem markers in pituitary adenomas. Using flow cytometry and the capacity to extrude nuclear fluorescent markers as the positive criterion, a side population of small cells has been described in human pituitary adenomas [5]. However, as commented above (see first part of this review), this capacity is not exclusive to stem cells; moreover, in a tumor it would not be uncommon for endothelial, blood, mesenchymal or immune cell precursors with such a stem characteristic to be present.

In 2009, Yu's group [101] proposed the existence of cancer stem cells in pituitary adenomas. Culturing dispersed cells from adenomas in serum-free conditions optimized for stem cells, they obtained spheres which expressed CD133 and nestin. However, as discussed above (first part of review), these are currently viewed as nonoptimal markers of ASC as they are restricted to specific stem populations (nestin) or not exclusive to stem cells $[16,60-63,102]$. Yu's team [101] also detected OCT4 mRNA expression, but none of the other bona fide stem cell markers (Sox2, Sox9, GFRa2). When they treated the spheres with a cocktail of hypothalamic peptides, they could detect pituitary hormones secreted into the medium. Although interesting, due to technical constraints it 
was not possible to demonstrate that the hormones were derived from the differentiated cells of the spheres rather than from contaminant cells present when the cultures were initially set up. Stem cell immortality was suggested by the fact that sphere numbers were increased by passaging, and injecting the spheres into the brains of nude mice led to tumors containing human $\mathrm{GH}$-expressing cells which were easily distinguished from mouse GH cells using a specific antibody. However, while the data are suggestive, the use of nonpurified cell populations for culturing and the suboptimal characterization of the resulting spheres leave room for alternative explanations. It cannot be excluded, for example, that the spheres arose from mesenchymal progenitors present in the adenomas or that the adenomas were contaminated with surrounding GH secretory cells.

In 2010, Florio's group [103] reported preliminary results from culturing pituitary adenomas as pituispheres; however, the full results have not yet been published. More recently, a series of somatotroph $(\mathrm{n}=14)$ and nonfunctioning pituitary adenomas (NFPA, $\mathrm{n}=21$ ) have been compared with normal human pituitary $(\mathrm{n}=10)$ in relation to GPS markers, using qRT-PCR and immunostaining [104]. Interestingly, NFPA expressed substantially $(>3 \times)$ more GFRA2 mRNA than did the normal pituitaries. By contrast, somatotroph adenomas expressed half as much GFRA2 as normal pituitaries. In the normal pituitary, GFRa2 was localized to basophilic cell clusters and Rathke's cysts within the MZ and was not coexpressed with hormones (GH, PRL, LH, FSH or TSH). However, colocalization of GFRa2 and hormones was observed in few cells referred to as 'ACTH' (which could also have been POMC non-ACTH cells as the antibody could not distinguish between those two cell types).

In agreement with previous results $[15,18]$, GFRA2 cells in normal pituitary also coexpress the ligand neurturin and the receptor RET but are negative for S100b and GFAP which are folliculostellate markers. However, Mathioudakis et al. [104] did not find colocalization of RET with $\mathrm{GH}+$ cells in the AP, a result that contradicts previous research in both rodents and humans $[18,90,91,97]$. Overall, the study strongly suggests that NFPA are niche cell derived, but secretory adenomas are not [104]. There are, however, some technical issues that need to be further addressed before the hypothesis can progress to a theory.

In parallel with these few recent investigations into the possibility of adenomas originating from stem cells, there are several studies focused on testing whether human adenomas are resistant to cell death in comparison to normal pituitary and if apoptosis is increased with treatment with analogs [88, 89, 105-107]. However, as commented above, these studies have the drawback of having used, seen from today, low sensitive or nonquantitative techniques such as colorimetric TUNEL or electronic microscopy. In general, the index of apoptosis in normal human pituitary was difficult to determine, and secretory adenomas presented higher rates of apoptosis than NFPAs did. Bromocriptine could increase the apoptosis index in responsive adenomas [107, 108].

A recent report described the expression of RET, GDNF, ARF and p53 in somatotrophs but not in NFPA adenomas in order to ascertain whether the dependence death pathway is affected in those tumors [94]. The apoptotic pathway is conserved in acromegaly primary cultures when the cells are deprived of GDNF, so that RET gets processed and the intracellular fragment induces cEBP-alpha binding to the human Pit-1 promoter to accumulate Pit-1, leading to p14Arf expression, p53 stabilization and apoptosis. However, in acromegaly tumors, GDNF is consistently overexpressed and the RET/pathway is blocked suggesting a survival loop. Future studies will be needed to identify the origin of each type of pituitary adenoma in relation to stem cell recruitment or resistance to programmed cell death.

\section{GPS Stem Cells and CRP}

$\mathrm{CRP}$ are AP tumors originating from nonsecretory cells and frequently located adjacent to or in the vicinity of the MZ. There are two types of CRP, adamantinomatous and papillary CRP with different histology and age at presentation. Adamantinomatous CRP are characteristic of children and present activating mutations in exon 3 of beta-catenin, leading to nuclear rather than submembrane expression of beta-catenin [109, 110]. Papillary CRP are characteristic of adults, are negative for betacatenin mutations, but have recently been shown to present the V600E mutation of BRAF [111].

Martinez-Barbera's group [112] have expressed the exon 3 mutation of beta-catenin under control of the Hex1 promoter, a gene that is characteristic of Rathke's Pouch progenitors. The Hesx1Cre/+;Ctnnb1+/lox(ex3) mice showed a marked hypopituitarism due to abnormal pituitary development. Clusters of cells expressing nuclear beta-catenin were present in the embryonic pituitary and remained after birth. After the 5th week, aggressive pituitary tumors containing nuclear beta-catenin clusters were seen. Similar clusters were seen in human adamantinomatous CRP. Human and mouse tumors expressed abundantly Sox 9 and Sox 2 around the clusters, while clusters themselves present slight differences between 
mice and humans. Clusters found in human CRP were negative for both Sox 9 and Sox2. However, a proportion of clusters found in mice tumors were positive for Sox2. Cluster cells had longer telomeres and express mitogenic factors such as EGF, SHH, BMP, FGF and Wnt-related genes such as the hedgehog receptor Ptch1 $[69,112]$.

Since these studies strongly suggested that progenitors play a role in the genesis of the tumors in mice and even that they could be implicated in human adamantinomatous CRP, the same group recently expressed the exon 3 beta-catenin mutation in the Sox 2 promoter-CRE-ERT2/ loxP-EYFP mice (see the section In vivo Tracing: Following the Differentiation Trajectory of AP GPS Stem Cells in the AP) [71]. These mice also presented aggressive pituitary tumors, negative for hormone expression with whorl-like clusters positive for nuclear beta-catenin like in human adamantinomatous CRP, although they did not present calcifications, wet keratine or palisade, also characteristic of the human tumors. Surprisingly, tumors in these mice were negative for YFP, demonstrating that the cells did not come from the Sox $2+$ beta-catenin-mutated cells. The investigators studied and discarded any altered recombination in the nonfluorescent tumors, which presented all the expected alleles at the DNA level but not recombined EYFP and beta-catenin. But the most interesting result was found at the periphery of the tumors where tiny clusters of recombined YFP+ cells were located expressing nuclear mutated beta-catenin and markers indicating activation of the Wnt and other embryonic pathways (Wnt, Shh, Bmp and Fgf). The conclusion opens up a completely new avenue, suggesting that tumors can originate not from a mutated stem cell itself but from its neighbors due to a nonautonomous mechanism that exposes them to very high levels of factors which the mutated stem cell secretes.

A series of human CRP ( $\mathrm{n}=18$ adamantinomatous, $\mathrm{n}=2$ papillary) and normal pituitary $(\mathrm{n}=4)$ were compared for GPS stem marker expression [15]. CRP, but not normal AP cells, express all GPS stem markers studied (GFRa3, RET, OCT4, KLF4, SOX2, SOX9, beta-catenin). As expected, adamantinomatous CRP present many cells with nuclear beta-catenin. Although colocalization studies were not performed, it was clear from a morphological analysis that the stem markers are coexpressed by tumor cells except in the case of RET and GFRa3. In both types of CRP, each of these markers appears to be expressed in contiguous rather than the same cells. These data are in contrast with what is seen in normal human GPS cells in the niche $[15,18]$ (fig. 1) and suggest that altered coexpression is associated with CRP.

\section{Conclusions}

Recent findings suggest that in the normal AP cells undergo slow but continuous renewal. The MZ niche generates stem cells that are recruited by the AP; on leaving the niche, these cells undergo commitment and differentiation, ultimately becoming integrated as secretory hormone and, probably, folliculostellate cells. As yet, neither the underlying molecular mechanisms nor whether different pathways give rise to different AP cell types are known. Nor is it known how pituitary stem cell maintenance or recruitment might be regulated from outside the gland. By comparison, the hematopoietic stem cell niche is known to be regulated by hormones (erythropoietin and colony-stimulating factors) and by circadian activity of the sympathetic nervous system [60, 113-115]. One plausible hypothesis is that the hypothalamus will be found to regulate cell turnover in the pituitary, either as a whole or in terms of individual processes.

The discoveries of a stem cell niche and the continuous recruitment of cells from it imply the involvement of regulated apoptosis in maintaining the normal balance of AP cell number and thus organ size. Recent evidence shows that programmed cell death does occur in the normal AP, most probably in areas discrete from the niche, and with potential mechanistic links with stem cell generation via RET. However, these mechanisms also need much more analysis, not least to understand their regulation. In particular, the contribution of the niche and/or apoptosis to AP pathology, whether hypofunctional hypopituitarism or hyperfunctional adenomas, is an area for further investigation with recently developed, more sensitive technologies. Ultimately, we can aim to elucidate how cell turnover is regulated during physiological adaptation of the AP (puberty, pregnancy, lactation), recruitment from the niche and cell death, and dysregulated in AP pathologies.

\section{Acknowledgements}

We thank Pamela Lear (Oxford University) for her comments and helpful revision of the manuscript. We thank Sihara PerezRomero, Ana Senra and Maria Suarez-Fariña for their expert technical assistance. Dilek Bahar is a Fellow of Erciyes University (Turkey).

The work leading to this article was supported by the following grants to C.V.A.: Fondo Social Europeo of the European Community and Ministerio de Economía y Competititvidad (2013BFU46109-R) and Xunta de Galicia REDICENT network (R2014-050). 


\section{References}

1 Melmed S: Mechanisms for pituitary tumorigenesis: the plastic pituitary. J Clin Invest 2003; 112:1603-1618.

-2 Perez-Castro C, Renner U, Haedo MR, Stalla GK, Arzt E: Cellular and molecular specificity of pituitary gland physiology. Physiol Rev 2012; 92:1-38.

-3 Ezzat S, Asa SL, Couldwell WT, Barr CE, Dodge WE, Vance ML, McCutcheon IE: The prevalence of pituitary adenomas: a systematic review. Cancer 2004;101:613-619.

4 Castinetti F, Davis SW, Brue T, Camper SA: Pituitary stem cell update and potential implications for treating hypopituitarism. Endocr Rev 2011;32:453-471.

5 Vankelecom H, Gremeaux L: Stem cells in the pituitary gland: a burgeoning field. Gen Comp Endocrinol 2010;166:478-488.

-6 Vankelecom H, Chen J: Pituitary stem cells: where do we stand? Mol Cell Endocrinol 2014; 385:2-17.

7 Tang F, Barbacioru C, Bao S, Lee C, Nordman E, Wang X, Lao K, Surani MA: Tracing the derivation of embryonic stem cells from the inner cell mass by single-cell RNA-Seq analysis. Cell Stem Cell 2010;6:468-478.

-8 Pera MF, Tam PP: Extrinsic regulation of pluripotent stem cells. Nature 2010;465:713-720.

$\checkmark 9$ Pera MF: Defining pluripotency. Nat Methods 2010;7:885-887.

10 Kalkan T, Smith A: Mapping the route from naive pluripotency to lineage specification. Philos Trans R Soc Lond B Biol Sci 2014;369: 20130540.

-11 Bi W, Deng JM, Zhang Z, Behringer RR, de Crombrugghe B: Sox 9 is required for cartilage formation. Nat Genet 1999;22:85-89.

$\checkmark 12$ Formeister EJ, Sionas AL, Lorance DK, Barkley CL, Lee GH, Magness ST: Distinct SOX9 levels differentially mark stem/progenitor populations and enteroendocrine cells of the small intestine epithelium. Am J Physiol Gastrointest Liver Physiol 2009;296:G1108-G1118.

-13 Scott CE, Wynn SL, Sesay A, Cruz C, Cheung M, Gomez Gaviro MV, Booth S, Gao B, Cheah KS, Lovell-Badge R, Briscoe J: SOX9 induces and maintains neural stem cells. Nat Neurosci 2010;13:1181-1189.

14 Mardaryev AN, Meier N, Poterlowicz K, Sharov AA, Sharova TY, Ahmed MI, Rapisarda V, Lewis C, Fessing MY, Ruenger TM, Bhawan J, Werner S, Paus R, Botchkarev VA: Lhx2 differentially regulates Sox9, Tcf4 and Lgr5 in hair follicle stem cells to promote epidermal regeneration after injury. Development 2011;138: 4843-4852.

15 Garcia-Lavandeira M, Saez C, Diaz-Rodriguez E, Perez-Romero S, Senra A, Dieguez C, Japon MA, Alvarez CV: Craniopharyngiomas express embryonic stem cell markers (SOX2, OCT4, KLF4, and SOX9) as pituitary stem cells but do not coexpress RET/GFRA3 receptors. J Clin Endocrinol Metab 2012;97:E80-E87.

-16 Alvarez CV, Garcia-Lavandeira M, GarciaRendueles ME, Diaz-Rodriguez E, Garcia-Rendueles AR, Perez-Romero S, Vila TV, Rodrigues JS, Lear PV, Bravo SB: Defining stem cell types: understanding the therapeutic potential of ESCs, ASCs, and iPS cells. J Mol Endocrinol 2012;49:R89-R111.

17 Kawaguchi Y: Sox9 and programming of liver and pancreatic progenitors. J Clin Invest 2013; 123:1881-1886.

18 Garcia-Lavandeira M, Quereda V, Flores I, Saez C, Diaz-Rodriguez E, Japon MA, Ryan AK, Blasco MA, Dieguez C, Malumbres M, Alvarez CV: A GRFa2/Prop1/stem (GPS) cell niche in the pituitary. PLoS One 2009;4:e4815.

19 Meng X, Lindahl M, Hyvonen ME, Parvinen M, de Rooij DG, Hess MW, Raatikainen-Ahokas A, Sainio K, Rauvala H, Lakso M, Pichel JG, Westphal H, Saarma M, Sariola H: Regulation of cell fate decision of undifferentiated spermatogonia by GDNF. Science 2000;287:14891493.

20 Costoya JA, Hobbs RM, Barna M, Cattoretti G, Manova K, Sukhwani M, Orwig KE, Wolgemuth DJ, Pandolfi PP: Essential role of Plzf in maintenance of spermatogonial stem cells. Nat Genet 2004;36:653-659.

21 Linher K, Wu D, Li J: Glial cell line-derived neurotrophic factor: an intraovarian factor that enhances oocyte developmental competence in vitro. Endocrinology 2007;148:4292-4301.

22 Kawamura K, Ye Y, Kawamura N, Jing L, Groenen P, Gelpke MS, Rauch R, Hsueh AJ, Tanaka T: Completion of Meiosis I of preovulatory oocytes and facilitation of preimplantation embryo development by glial cell line-derived neurotrophic factor. Dev Biol 2008;315:189202.

23 Li J, Klein C, Liang C, Rauch R, Kawamura K, Hsueh AJ: Autocrine regulation of early embryonic development by the artemin-GFRA3 (GDNF family receptor-alpha 3) signaling system in mice. FEBS Lett 2009;583:24792485.

24 Fonseca-Pereira D, Arroz-Madeira S, Rodrigues-Campos M, Barbosa IA, Domingues RG, Bento T, Almeida AR, Ribeiro H, Potocnik AJ, Enomoto H, Veiga-Fernandes H: The neurotrophic factor receptor RET drives haematopoietic stem cell survival and function. Nature 2014;514:98-101.

25 Chen J, Hersmus N, Van Duppen V, Caesens P, Denef C, Vankelecom H: The adult pituitary contains a cell population displaying stem/progenitor cell and early embryonic characteristics. Endocrinology 2005; 146: 3985-3998.

26 Lepore DA, Roeszler K, Wagner J, Ross SA, Bauer K, Thomas PQ: Identification and enrichment of colony-forming cells from the adult murine pituitary. Exp Cell Res 2005;308: 166-176.

27 Chen J, Crabbe A, Van Duppen V, Vankelecom $\mathrm{H}$ : The notch signaling system is present in the postnatal pituitary: marked expression and regulatory activity in the newly discovered side population. Mol Endocrinol 2006;20:32933307.

28 Lepore DA, Jokubaitis VJ, Simmons PJ, Roeszler KN, Rossi R, Bauer K, Thomas PQ: A role for angiotensin-converting enzyme in the characterization, enrichment, and proliferation potential of adult murine pituitary colony-forming cells. Stem Cells 2006;24:23822390.

29 Lepore DA, Thomas GP, Knight KR, Hussey AJ, Callahan T, Wagner J, Morrison WA, Thomas PQ: Survival and differentiation of pituitary colony-forming cells in vivo. Stem Cells 2007;25:1730-1736.

-30 Fauquier T, Rizzoti K, Dattani M, Lovell-Badge $\mathrm{R}$, Robinson IC: SOX2-expressing progenitor cells generate all of the major cell types in the adult mouse pituitary gland. Proc Natl Acad Sci USA 2008; 105:2907-2912.

31 Chen J, Gremeaux L, Fu Q, Liekens D, Van Laere S, Vankelecom H: Pituitary progenitor cells tracked down by side population dissection. Stem Cells 2009;27:1182-1195.

32 Correr S, Motta P: The rat pituitary cleft: a correlated study by scanning and transmission electron microscopy; in Allen DJ (ed): Three Dimensional Microanatomy of Cells and Tissue Surfaces: Proceedings of the Symposium on Three Dimensional Microanatomy Held in Mexico City, Aug. 17-23, 1980. New York, Elsevier/North-Holland, 1981, pp 69-82.

33 Correr S, Motta PM: The rat pituitary cleft: a correlated study by scanning and transmission electron microscopy. Cell Tissue Res 1981;215: 515-529.

34 Correr S, Motta PM: A scanning electron-microscopic study of 'supramarginal cells' in the pituitary cleft of the rat. Cell Tissue Res 1985; 241:275-281.

35 Le Tissier PR, Hodson DJ, Lafont C, Fontanaud P, Schaeffer M, Mollard P: Anterior pituitary cell networks. Front Neuroendocrinol 2012;33: 252-266.

36 Yoshida S, Kato T, Yako H, Susa T, Cai LY, Osuna M, Inoue K, Kato Y: Significant quantitative and qualitative transition in pituitary stem/ progenitor cells occurs during the postnatal development of the rat anterior pituitary. J Neuroendocrinol 2011;23:933-943.

37 Anversa P, Kajstura J, Leri A, Loscalzo J: Tissuespecific adult stem cells in the human lung. Nat Med 2011;17:1038-1039.

38 Kajstura J, Rota M, Hall SR, Hosoda T, D’Amario D, Sanada F, Zheng H, Ogorek B, Rondon-Clavo C, Ferreira-Martins J, Matsuda A, Arranto C, Goichberg P, Giordano G, Haley KJ, Bardelli S, Rayatzadeh H, Liu X, Quaini F, Liao R, Leri A, Perrella MA, Loscalzo J, Anversa P: Evidence for human lung stem cells. N Engl J Med 2011;364:1795-1806.

39 Gage PJ, Roller ML, Saunders TL, Scarlett LM, Camper SA: Anterior pituitary cells defective in the cell-autonomous factor, df, undergo cell lineage specification but not expansion. Development 1996;122:151-160.

40 Sornson MW, Wu W, Dasen JS, Flynn SE, Norman DJ, O'Connell SM, Gukovsky I, Carriere C, Ryan AK, Miller AP, Zuo L, Gleiberman AS, Andersen B, Beamer WG, Rosenfeld MG: Pituitary lineage determination by the Prophet of Pit-1 homeodomain factor defective in Ames dwarfism. Nature 1996;384:327-333. 
-41 Wu W, Cogan JD, Pfaffle RW, Dasen JS, Frisch H, O'Connell SM, Flynn SE, Brown MR, Mullis PE, Parks JS, Phillips JA 3rd, Rosenfeld MG: Mutations in PROP1 cause familial combined pituitary hormone deficiency. Nat Genet 1998; 18:147-149.

42 Nasonkin IO, Ward RD, Raetzman LT, Seasholtz AF, Saunders TL, Gillespie PJ, Camper SA: Pituitary hypoplasia and respiratory distress syndrome in Prop1 knockout mice. Hum Mol Genet 2004;13:2727-2735.

-43 Ward RD, Raetzman LT, Suh H, Stone BM, Nasonkin IO, Camper SA: Role of PROP1 in pituitary gland growth. Mol Endocrinol 2005;19: 698-710.

-44 Kelberman D, Rizzoti K, Lovell-Badge R, Robinson IC, Dattani MT: Genetic regulation of pituitary gland development in human and mouse. Endocr Rev 2009;30:790-829.

-45 Olson LE, Tollkuhn J, Scafoglio C, Krones A, Zhang J, Ohgi KA, Wu W, Taketo MM, Kemler R, Grosschedl R, Rose D, Li X, Rosenfeld MG: Homeodomain-mediated beta-catenin-dependent switching events dictate cell-lineage determination. Cell 2006;125:593-605.

-46 Sugiyama Y, Ikeshita N, Shibahara H, Yamamoto D, Kawagishi M, Iguchi G, Iida K, Takahashi Y, Kaji H, Chihara K, Okimura Y: A PROP1-binding factor, AES cloned by yeast two-hybrid assay represses PROP1-induced Pit-1 gene expression. Mol Cell Endocrinol 2013;376:93-98

47 Chambers I, Tomlinson SR: The transcriptional foundation of pluripotency. Development 2009;136:2311-2322.

-48 Kopp JL, Ormsbee BD, Desler M, Rizzino A: Small increases in the level of Sox 2 trigger the differentiation of mouse embryonic stem cells. Stem Cells 2008;26:903-911.

49 Mitsui K, Tokuzawa Y, Itoh H, Segawa K, Murakami M, Takahashi K, Maruyama M, Maeda M, Yamanaka S: The homeoprotein Nanog is required for maintenance of pluripotency in mouse epiblast and ES cells. Cell 2003;113:631642.

50 Niwa H, Miyazaki J, Smith AG: Quantitative expression of Oct-3/4 defines differentiation, dedifferentiation or self-renewal of ES cells. Nat Genet 2000;24:372-376.

-51 Barker N, van Es JH, Kuipers J, Kujala P, van den Born M, Cozijnsen M, Haegebarth A, Korving J, Begthel H, Peters PJ, Clevers H: Identification of stem cells in small intestine and colon by marker gene Lgr5. Nature 2007;449:1003-1007.

- 52 Imayoshi I, Isomura A, Harima Y, Kawaguchi K, Kori H, Miyachi H, Fujiwara T, Ishidate F, Kageyama R: Oscillatory control of factors determining multipotency and fate in mouse neural progenitors. Science 2013;342:1203-1208.

53 Lendahl U, Zimmerman LB, McKay RD: CNS stem cells express a new class of intermediate filament protein. Cell 1990;60:585-595.

-54 Krylyshkina O, Chen J, Mebis L, Denef C, Vankelecom $\mathrm{H}$ : Nestin-immunoreactive cells in rat pituitary are neither hormonal nor typical folliculo-stellate cells. Endocrinology 2005;146: 2376-2387.

55 Gautron L, De-Smedt V, Laye S: Age-related changes in nestin immunoreactivity in the rat pituitary gland. Neuroendocrinology 2009;90: 19-30.

56 Perez-Millan MI, Berner SI, Luque GM, De Bonis C, Sevlever G, Becu-Villalobos D, Cristina C: Enhanced nestin expression and small blood vessels in human pituitary adenomas. Pituitary 2013;16:303-310.

57 Horvath E, Coire CI, Kovacs K, Smyth HS: Folliculo-stellate cells of the human pituitary as adult stem cells: examples of their neoplastic potential. Ultrastruct Pathol 2010;34:133-139.

58 Gleiberman AS, Michurina T, Encinas JM, Roig JL, Krasnov P, Balordi F, Fishell G, Rosenfeld MG, Enikolopov G: Genetic approaches identify adult pituitary stem cells. Proc Natl Acad Sci USA 2008;105:6332-6337.

59 Galichet C, Lovell-Badge R, Rizzoti K: NestinCre mice are affected by hypopituitarism, which is not due to significant activity of the transgene in the pituitary gland. PLoS One 2010;5:e11443.

60 Mendez-Ferrer S, Michurina TV, Ferraro F, Mazloom AR, Macarthur BD, Lira SA, Scadden DT, Ma'ayan A, Enikolopov GN, Frenette PS: Mesenchymal and haematopoietic stem cells form a unique bone marrow niche. Nature 2010;466:829-834.

61 Ding L, Saunders TL, Enikolopov G, Morrison SJ: Endothelial and perivascular cells maintain haematopoietic stem cells. Nature 2012;481: 457-462.

62 Kunisaki Y, Bruns I, Scheiermann C, Ahmed J, Pinho S, Zhang D, Mizoguchi T, Wei Q, Lucas D, Ito K, Mar JC, Bergman A, Frenette PS: Arteriolar niches maintain haematopoietic stem cell quiescence. Nature 2013;502:637-643.

63 Mabuchi Y, Houlihan DD, Akazawa C, Okano $\mathrm{H}$, Matsuzaki Y: Prospective isolation of murine and human bone marrow mesenchymal stem cells based on surface markers. Stem Cells Int 2013;2013:507301.

64 Gilyarov AV: Nestin in central nervous system cells. Neurosci Behav Physiol 2008;38:165-169.

65 Rotondo F, Kovacs K, Horvath E, Bell CD, Lloyd RV, Scheithauer BW: Immunohistochemical expression of nestin in the non-tumorous hypophysis and in pituitary neoplasms. Acta Neuropathol 2006;111:272-277.

66 Shamblott MJ, Axelman J, Littlefield JW, Blumenthal PD, Huggins GR, Cui Y, Cheng L, Gearhart JD: Human embryonic germ cell derivatives express a broad range of developmentally distinct markers and proliferate extensively in vitro. Proc Natl Acad Sci USA 2001;98: 113-118.

67 Bignami A, Raju T, Dahl D: Localization of vimentin, the nonspecific intermediate filament protein, in embryonal glia and in early differentiating neurons. In vivo and in vitro immunofluorescence study of the rat embryo with vimentin and neurofilament antisera. Dev Biol 1982;91:286-295.

68 Gremeaux L, Fu Q, Chen J, Vankelecom H: Activated phenotype of the pituitary stem/progenitor cell compartment during the earlypostnatal maturation phase of the gland. Stem Cells Dev 2012;21:801-813.

69 Andoniadou CL, Gaston-Massuet C, Reddy R, Schneider RP, Blasco MA, Le Tissier P, Jacques
TS, Pevny LH, Dattani MT, Martinez-Barbera JP: Identification of novel pathways involved in the pathogenesis of human adamantinomatous craniopharyngioma. Acta Neuropathol 2012; 124:259-271.

70 Rizzoti K, Akiyama H, Lovell-Badge R: Mobilized adult pituitary stem cells contribute to endocrine regeneration in response to physiological demand. Cell Stem Cell 2013;13:419-432.

71 Andoniadou CL, Matsushima D, Mousavy Gharavy SN, Signore M, Mackintosh AI, Schaeffer M, Gaston-Massuet C, Mollard P, Jacques TS, Le Tissier P, Dattani MT, Pevny LH, Martinez-Barbera JP: Sox2+ stem/progenitor cells in the adult mouse pituitary support organ homeostasis and have tumor-inducing potential. Cell Stem Cell 2013;13:433-445.

-72 Tatsi C, Sertedaki A, Voutetakis A, Valavani E Magiakou MA, Kanaka-Gantenbein C, Chrousos GP, Dacou-Voutetakis C: Pituitary stalk interruption syndrome and isolated pituitary hypoplasia may be caused by mutations in holoprosencephaly-related genes. J Clin Endocrinol Metab 2013;98:E779-E784.

73 Suga H, Kadoshima T, Minaguchi M, Ohgushi M, Soen M, Nakano T, Takata N, Wataya T, Muguruma K, Miyoshi H, Yonemura S, Oiso Y, Sasai Y: Self-formation of functional adenohypophysis in three-dimensional culture. Nature 2011;480:57-62.

74 Dincer Z, Piao J, Niu L, Ganat Y, Kriks S, Zimmer B, Shi SH, Tabar V, Studer L: Specification of functional cranial placode derivatives from human pluripotent stem cells. Cell Rep 2013;5: 1387-1402.

75 Horsley V, Aliprantis AO, Polak L, Glimcher LH, Fuchs E: NFATc1 balances quiescence and proliferation of skin stem cells. Cell 2008;132: 299-310.

76 Fuchs E, Horsley V: Ferreting out stem cells from their niches. Nat Cell Biol 2011;13:513518.

77 Jirawatnotai S, Aziyu A, Osmundson EC, Moons DS, Zou X, Kineman RD, Kiyokawa H: Cdk4 is indispensable for postnatal proliferation of the anterior pituitary. J Biol Chem 2004; 279:51100-51106.

-78 Rane SG, Cosenza SC, Mettus RV, Reddy EP: Germ line transmission of the Cdk4(R24C) mutation facilitates tumorigenesis and escape from cellular senescence. Mol Cell Biol 2002;22: 644-656.

79 Rane SG, Dubus P, Mettus RV, Galbreath EJ, Boden G, Reddy EP, Barbacid M: Loss of Cdk4 expression causes insulin-deficient diabetes and Cdk 4 activation results in beta-islet cell hyperplasia. Nat Genet 1999;22:44-52.

80 Martin J, Hunt SL, Dubus P, Sotillo R, NehmePelluard F, Magnuson MA, Parlow AF, Malumbres M, Ortega S, Barbacid M: Genetic rescue of Cdk4 null mice restores pancreatic betacell proliferation but not homeostatic cell number. Oncogene 2003;22:5261-5269.

-81 Fu Q, Gremeaux L, Luque RM, Liekens D, Chen J, Buch T, Waisman A, Kineman R, Vankelecom H: The adult pituitary shows stem/ progenitor cell activation in response to injury and is capable of regeneration. Endocrinology 2012;153:3224-3235. 
82 Fu Q, Vankelecom H: Regenerative capacity of the adult pituitary: multiple mechanisms of lactotrope restoration after transgenic ablation. Stem Cells Dev 2012;21:3245-3257.

83 Langlais D, Couture C, Kmita M, Drouin J: Adult pituitary cell maintenance: lineage-specific contribution of self-duplication. Mol Endocrinol 2013;27:1103-1112.

-84 Schneeberger M, Altirriba J, Garcia A, Esteban Y, Castano C, Garcia-Lavandeira M, Alvarez CV, Gomis R, Claret M: Deletion of miRNA processing enzyme Dicer in POMC-expressing cells leads to pituitary dysfunction, neurodegeneration and development of obesity. Mol Metab 2012;2:74-85.

-85 Nolan LA, Kavanagh E, Lightman SL, Levy A: Anterior pituitary cell population control: basal cell turnover and the effects of adrenalectomy and dexamethasone treatment. J Neuroendocrinol 1998;10:207-215.

86 Arnold K, Sarkar A, Yram MA, Polo JM, Bronson R, Sengupta S, Seandel M, Geijsen N, Hochedlinger K: Sox $2+$ adult stem and progenitor cells are important for tissue regeneration and survival of mice. Cell Stem Cell 2011;9:317329.

-87 Furuyama K, Kawaguchi Y, Akiyama H, Horiguchi M, Kodama S, Kuhara T, Hosokawa S, Elbahrawy A, Soeda T, Koizumi M, Masui T, Kawaguchi M, Takaori K, Doi R, Nishi E, Kakinoki R, Deng JM, Behringer RR, Nakamura T, Uemoto S: Continuous cell supply from a Sox9-expressing progenitor zone in adult liver, exocrine pancreas and intestine. Nat Genet 2011;43:34-41.

-88 Kulig E, Jin L, Qian X, Horvath E, Kovacs K, Stefaneanu L, Scheithauer BW, Lloyd RV: Apoptosis in nontumorous and neoplastic human pituitaries: expression of the Bcl-2 family of proteins. Am J Pathol 1999;154:767-774.

89 Vidal S, Horvath E, Kovacs K, Scheithauer BW, Lloyd RV, Kontogeorgos G: Ultrastructural features of apoptosis in human pituitary adenomas. Ultrastruct Pathol 2001;25:85-92.

-90 Urbano AG, Suarez-Penaranda JM, Dieguez C, Alvarez CV: GDNF and RET-gene expression in anterior pituitary-cell types. Endocrinology 2000;141:1893-1896.

-91 Japon MA, Urbano AG, Saez C, Segura DI, Cerro AL, Dieguez C, Alvarez CV: Glial-derived neurotropic factor and RET gene expression in normal human anterior pituitary cell types and in pituitary tumors. J Clin Endocrinol Metab 2002;87:1879-1884.

-92 Canibano C, Rodriguez NL, Saez C, Tovar S, Garcia-Lavandeira M, Borrello MG, Vidal A, Costantini F, Japon M, Dieguez C, Alvarez CV: The dependence receptor Ret induces apoptosis in somatotrophs through a Pit-1/p53 pathway, preventing tumor growth. EMBO J 2007; 26:2015-2028.

93 Delcros JG, Mehlen P: Dependence receptors: life or death choices. Bull Cancer 2013;100: 1261-1274.
$\$ 94$ Diaz-Rodriguez E, Garcia-Rendueles AR, Ibanez-Costa A, Gutierrez-Pascual E, GarciaLavandeira M, Leal A, Japon MA, Soto A, Venegas E, Tinahones FJ, Garcia-Arnes JA, Benito P, Angeles Galvez M, Jimenez-Reina L, Bernabeu I, Dieguez C, Luque RM, Castano JP, Alvarez CV: Somatotropinomas, but not nonfunctioning pituitary adenomas, maintain a functional apoptotic RET/Pit1/ARF/ p53 pathway that is blocked by excess GDNF. Endocrinology 2014;155:4329-4340.

95 Diaz-Rodriguez E, Garcia-Lavandeira M, Perez-Romero S, Senra A, Canibano C, Palmero I, Borrello MG, Dieguez C, Alvarez CV: Direct promoter induction of p19Arf by Pit-1 explains the dependence receptor RET/Pit-1/ p53-induced apoptosis in the pituitary somatotroph cells. Oncogene 2012;31:28242835.

\$6 Garcia-Lavandeira M, Diaz-Rodriguez E, Garcia-Rendueles ME, Rodrigues JS, PerezRomero S, Bravo SB, Alvarez CV: Functional role of the RET dependence receptor, GFRa co-receptors and ligands in the pituitary. Front Horm Res 2010;38:127-138.

-97 Guillou A, Romano N, Bonnefont X, Le Tissier P, Mollard P, Martin AO: Modulation of the tyrosine kinase receptor Ret/glial cell-derived neurotrophic factor (GDNF) signaling: a new player in reproduction induced anterior pituitary plasticity? Endocrinology 2011;152: 515-525.

-98 Jaubert A, Drutel G, Leste-Lasserre T, Ichas F, Bresson-Bepoldin L: Tyrosine hydroxylase and dopamine transporter expression in lactotrophs from postlactating rats: involvement in dopamine-induced apoptosis. Endocrinology 2007;148:2698-2707.

-99 Gadelha MR, Trivellin G, Hernandez Ramirez LC, Korbonits M: Genetics of pituitary adenomas. Front Horm Res 2013;41:111-140.

100 Maheshwari HG, Prezant TR, Herman-Bonert V, Shahinian H, Kovacs K, Melmed S: Long-acting peptidomimergic control of gigantism caused by pituitary acidophilic stem cell adenoma. J Clin Endocrinol Metab 2000; 85:3409-3416.

101 Xu Q, Yuan X, Tunici P, Liu G, Fan X, Xu M, Hu J, Hwang JY, Farkas DL, Black KL, Yu JS: Isolation of tumour stem-like cells from benign tumours. Br J Cancer 2009;101:303-311.

102 Karbanova J, Missol-Kolka E, Fonseca AV, Lorra C, Janich P, Hollerova H, Jaszai J, Ehrmann J, Kolar Z, Liebers C, Arl S, Subrtova D, Freund D, Mokry J, Huttner WB, Corbeil D: The stem cell marker CD133 (Prominin-1) is expressed in various human glandular epithelia. J Histochem Cytochem 2008;56:977-993.

103 Florio T: Recent evidence of putative human pituitary adenoma tumor stem cells (abstract S-3.3:37). 14th Eur Neuroendocr Assoc Congr, Liège, 2010.

104 Mathioudakis N, Sundaresh R, Larsen A, Ruff W, Schiller J, Guerrero-Cazares H, Burger P, Salvatori R, Quinones-Hinojosa A: Expression of the pituitary stem/progenitor marker GFRalpha2 in human pituitary adenomas and normal pituitary. Pituitary 2015;18:31-41.
05 Kontogeorgos G, Sambaziotis D, Piaditis G, Karameris A: Apoptosis in human pituitary adenomas: a morphologic and in situ end-labeling study. Mod Pathol 1997;10:921-926.

106 Green VL, White MC, Hipkin LJ, Jeffreys RV, Foy PM, Atkin SL: Apoptosis and p53 suppressor gene protein expression in human anterior pituitary adenomas. Eur J Endocrinol 1997;136:382-387.

107 Kontogeorgos G, Horvath E, Kovacs K, Coire C, Lloyd RV, Scheithauer BW, Smyth HS Morphologic changes of prolactin-producing pituitary adenomas after short treatment with dopamine agonists. Acta Neuropathol 2006; 111:46-52.

108 Saitoh Y, Arita N, Ohnishi T, Ekramullah S, Takemura K, Hayakawa T: Absence of apoptosis in somatotropinomas treated with octreotide. Acta Neurochir (Vienna) 1997;139: 851-856.

109 Sekine S, Shibata T, Kokubu A, Morishita Y, Noguchi M, Nakanishi Y, Sakamoto M, Hirohashi S: Craniopharyngiomas of adamantinomatous type harbor beta-catenin gene mutations. Am J Pathol 2002;161:1997-2001.

110 Buslei R, Nolde M, Hofmann B, Meissner S, Eyupoglu IY, Siebzehnrubl F, Hahnen E, Kreutzer J, Fahlbusch R: Common mutations of beta-catenin in adamantinomatous craniopharyngiomas but not in other tumours originating from the sellar region. Acta Neuropathol 2005;109:589-597.

111 Brastianos PK, Taylor-Weiner A, Manley PE, Jones RT, et al: Exome sequencing identifies BRAF mutations in papillary craniopharyngiomas. Nat Genet 2014;46:161-165.

- 112 Gaston-Massuet C, Andoniadou CL, Signore M, Jayakody SA, Charolidi N, Kyeyune R, Vernay B, Jacques TS, Taketo MM, Le Tissier P, Dattani MT, Martinez-Barbera JP: Increased Wingless (Wnt) signaling in pituitary progenitor/stem cells gives rise to pituitary tumors in mice and humans. Proc Natl Acad Sci USA 2011;108:11482-11487.

113 Katayama Y, Battista M, Kao WM, Hidalgo A, Peired AJ, Thomas SA, Frenette PS: Signals from the sympathetic nervous system regulate hematopoietic stem cell egress from bone marrow. Cell 2006;124:407-421.

114 Lucas D, Battista M, Shi PA, Isola L, Frenette PS: Mobilized hematopoietic stem cell yield depends on species-specific circadian timing. Cell Stem Cell 2008;3:364-366.

115 Mendez-Ferrer S, Lucas D, Battista M, Frenette PS: Haematopoietic stem cell release is regulated by circadian oscillations. Nature 2008;452:442-447.

116 Mazumdar J, O’Brien WT, Johnson RS, LaManna JC, Chavez JC, Klein PS, Simon MC: $\mathrm{O}_{2}$ regulates stem cells through Wnt/betacatenin signalling. Nat Cell Biol 2010;12: 1007-1013. 